\title{
캠퍼스 국제화에 대한 국내 학생들의 인식 연구*
}

임희진(林希珍)**

김제희(金帝希)

정소현 (鄭昭賢)

정하영(鄭夏瑛)

김현성(金炫聖)

\section{논문 요약}

그 동안 고등교육의 국제화와 관련된 국내의 연구들은 주로 외국인 유학생의 한국 유학생활에 대한 경험 및 인식에 초점을 맞추고 있었다. 그러나 실제 캠퍼스 현장에서 외국인 유학생의 유입으로 인해 다양한 방면에서 영향을 받고 있을 국내 학생들이 어떠한 관점에서 현재의 국제화 현상을 인식하고 있는지에 대한 관심은 매우 미비하였다. 따라서 본 연구는 최근 가속화되는 외국인 유학생의 유입으로 인해 캠퍼스 구성원이 다양해지는 현 상을 '캠퍼스 국제화'로 정의하고, 이에 대한 국내 학생들의 인식을 면담을 통해 탐색하였다. 이를 위해 총 24명의 $\mathrm{A}$ 대학 학부생과 대학원생을 대상으로 반구조화된 면담을 실시하였으며, 주요 연구 결과는 다음과 같다. 첫째, 국내 학생들은 캠퍼스 국제화의 실효성에 대한 이상과 현실 사이의 괴리감을 인식하고 있었다. 둘째, 국내학생들 은 외국인 유학생의 출신배경에 따라 그들의 유학동기, 학업태도와 학업 능력을 차별적으로 인식하고 있었으며, 이들의 출신배경에 따른 선호도에도 차이가 있는 것으로 나타났다. 셋째, 국내학생들은 외국인 유학생들을 함께 공부하고 연구하는 동료이기에 앞서, 챙겨줘야 하고 부담을 주는 '불편한 손님’으로 인식하고 있었으며 이러한 불편함의 정도는 학위과정과 전공분야에 따라 상이하게 나타났다. 넷째, 국내학생들은 입학전형, 자원배분(예: 기숙사, 장학금)등이 외국인 학생들에게 상대적으로 더욱 쉽게 제공된다고 인식하고 있어 상대적인 박탈감을 경 험하는 사례도 발견되었다. 이러한 연구 결과를 바탕으로 본 연구에서는 대학 기관과 정부가 국내 학생이 외국인 유학생의 유입으로 인해 직면할 수 있는 문제를 완화할 제도적 장치를 마련해야 할 필요성을 제시하고 있다.

주요어 : 고등교육 국제화, 국내 학생 인식, 학내 국제화, 캠퍼스 국제화

* 이 논문은 BK21 플러스 사업에 의하여 지원되었음 (관리번호 21B20130011080)

** 제1저자, 서울대학교 교육학과 박사과정, liyyhl@snu.ac.kr 


\section{I. 서론}

국가의 고등교육 경쟁력이 곧 국력으로 인식되면서 지난 20여 년간 고등교육 개혁을 위한 노 력들이 많은 국가에서 이루어졌다. 이 중 '국제화'는 세계적으로 고등교육 부문에 있어 가장 큰 변화를 초래한 핵심적 동인(엄상현·변기용, 2012)이었다고 볼 수 있다. 한국도 이러한 세계적 흐 름에 따라 2004년 스터디 코리아 프로젝트 (Study Korea Project)를 도입하였으며 그 결과 2013 년 기준 전국에 85,923여명의 외국인 유학생이 국내 고등교육 기관에 재학하고 있다(대학알리미, 2014). 이는 1996년에 약 2,000명 수준에 불과했던 외국인 유학생 규모에 비교했을 때 괄목적인 성장이라고 볼 수 있다. 따라서 이제 한국의 대학 캠퍼스에서도 외국인 유학생들을 발견하는 것 은 전혀 어려운 일이 아니며 대학 곳곳에서 외국인 유학생을 위한 영어 강좌 확충은 물론, 학습 과 한국 생활 전반을 지원하기 위한 다양한 프로그램(예: 버디프로그램, Peer-Tutoring, 한국문화 체험 프로그램 등) 및 외국인 유학생의 자치회가 대학 별로 활발하게 이루어지고 있다. 이처럼 정부와 대학들은 외국인 학생을 적극적으로 유치함에 따라 한국의 고등교육 경쟁력이 제고되고, 더 나아가 글로벌한 캠퍼스 구축을 통해 국내 학생들에게도 다양한 역량을 함양할 수 있는 기회 를 제공할 수 있을 것이라는 가정을 가지고 있다.

그러나 한국의 고등교육 국제화는 급속한 팽창으로 인해 그 질적 수준에 있어서는 다양한 문 제점이 제기되어 왔으며(나임순, 2006; 임수진·한규석, 2009; 이보경 외, 2013) 특히 이 중 국제화 의 질을 핵심적으로 가늠한다고 볼 수 있는 학생들 간의 질적 상호작용 부족(전재은, 2013; Jon, 2012; Jon \& Kim, 2011)은 그동안의 선행연구를 통해 지속적으로 제기되어 왔다. 이러한 맥락에 서 살펴보면 현재의 국제화 정책은 단순히 외국인 학생을 유치하는 데에만 그쳐있고, 대학 현장 에서의 실제적인 상호작용과 학습효과 수준을 고려하지 않는 일방적인 형태로 시행되고 있다고 봐도 무방할 것이다. 그럼에도 불구하고 정부와 대학에서는 캠퍼스 내에 다양한 외국인 유학생 들이 존재하는 것 자체로 성공적인 국제화를 이루었다는 성급한 결론을 내리는 오류를 범하기 쉽다(Wright \& Lander, 2003).

그동안 국내의 고등교육 국제화에 관한 연구의 대다수는 외국인 유학생의 유학경험과 인식을 분석하여 이들을 더 효과적으로 유치하고 지원할 수 있는 발판을 마련하려는 데에 초점이 맞추 어져왔다. 이는 기존의 고등교육 국제화에 대한 많은 정책적·학술적 관심은 주로 유학국의 교육 서비스 수요자인 '외국인 유학생'을 중심으로 이루어져온 맥락과 연결된다고 할 수 있다. 그러나 실제 외국인 유학생의 유입으로 인해 캠퍼스 현장에서 나타나는 다양한 환경적 변화를 직접적 으로 경험하고 또 그로 인해 실질적인 영향을 받는 것은 '움직이지 않는' 더 큰 규모의 자국 학생 들이라고 할 수 있다. 따라서 향후 보다 효과적인 국제화를 이루어내기 위해서는 외국인 학생들 의 유학 경험에만 초점을 맞추는 것이 아니라, 국내 학생들의 관점에서 인식되는 국제화의 현상 
과 경험에도 관심을 기울여야 할 필요가 있다.

따라서 본 연구에서는 대학의 주요 국제화 전략으로 사용되고 있는 '캠퍼스 국제화', 즉 외국 인 유학생 유입으로 인해 캠퍼스 구성원이 다양해지는 현상을 국내 학생들이 어떻게 인식하고 있는지 살펴보고, 그 속에 내포되어 있는 다층적인 사회, 문화, 제도적 요소들을 분석하여 관련 된 정책적 시사점을 도출하는 데 목적이 있다. 이처럼 국내 학생의 관점에서 바라보는 대학의 국제화는 그동안 큰 문제점으로 제기되어 온 외국인 유학생과의 부족한 상호작용(전재은, 2013; 임수진·한규석, 2009; Jon \& Kim, 2011)의 실제적인 원인을 보다 심층적으로 분석하고 해결하는 데 중요한 단서를 제공할 수 있는 유용한 근거가 될 것이다.

\section{․ 이론적 배경}

\section{1. 캠퍼스 국제화의 개념}

본 연구에서 사용하는 '캠퍼스 국제화’라는 개념은 '외국인 유학생의 유입으로 인해 캠퍼스 공간의 구성원이 다양해지는 현상’을 의미한다. '캠퍼스 국제화'는 본 연구에서 논의를 효과적으 로 이끌어내기 위해 조작적으로 도출한 개념으로써, 이는 'Internationalization at Home(이하 학 내 국제화)'에서1) 제시하는 주요 관점의 일부를 접목시켜 생성된 하위개념이라고 할 수 있다. 따라서 캠퍼스 국제화를 정의하는데 앞서 학내 국제화의 도입 맥락과 배경에 대한 이해가 선행 될 필요가 있다.

학내 국제화는 1980년대 후반 유럽에서 발족된 ERASMUS(유럽연합대학생교류프로그램)의 한계에 대한 논의(Crowther, 2000)에서부터 등장하였다고 볼 수 있다. Wächter(2003)는 실제 자 국을 떠나 외국으로 공부하러 갈 수 있는 학생의 규모와 범위는 매우 제한되어 있기 때문에 보 다 효과적인 국제화를 이루기 위해서는 ‘움직이지 않는' 자국 학생들에게 국제적인 교육 환경을 구축해야 할 필요성을 제시하였다. 이러한 맥락에서 도출된 '학내 국제화'의 개념은 ‘외국으로 떠나는 학생이나 교수의 유동성을 제외한 교내의 국제적 활동을 의미하며 포괄하는 범위 및 수준 또한 다양하다.

이처럼 학내국제화가 포괄하고 있는 범위는 굉장히 넓은 수준인데 이를 명료화하기 위해 Harrison \& Peacock(2009)은 학내 국제화가 추구하는 공통적인 특징을 총 6가지의 범주2)에서

1) 엄상현 · 변기용(2012)의 연구에서는 Internationalization at Home을 소개하는데 있어 '학내 국제화'라는 표 현을 사용, 본 연구에서도 이를 기준으로 서술하고자 한다.

2) Harrison\&Peacock(2009)은 학내국제화가 추구하는 여섯 가지의 특성으로 다음과 같은 내용을 제시한 바 있 다. 첫째, 외국인 학생의 유입을 통해 자국 학생들에게 이문화적 학습 기회 제공, 둘째, 자국 학생들에게 
서술하였으며 이 중 외국인 유학생의 캠퍼스 유입을 학내 국제화가 추구하는 바를 구현하는데 있어 핵심적인 요소로 간주하였다. 즉, 학내 국제화는 교내에 다양한 외국인 유학생의 존재 그 자체로 인해 자국 학생의 국제적 역량 강화가 가능할 것이라는 데 초점을 두고 있고, 이를 골자 로 많은 대학들이 외국인 유학생 유치를 통해 캠퍼스 구성원의 다양화를 꾀하고 있다.

이처럼 학내 국제화가 외국인 학생의 유입을 포함한 대학 내에서 이루어지고 있는 광범위한 수준과 범위의 국제적 활동을 모두 포함하는 포괄적인 개념이라면, 본 논문에서 제시하는 '캠퍼 스 국제화'는 학내국제화를 구현하기 위하여 각 정부와 대학이 캠퍼스 구성원을 다양화시키는 현상을 의미하는 하위개념이다. 캠퍼스 국제화 역시 다양한 문화적 배경을 가진 외국인 유학생 이 캠퍼스에 유입하게 되면, 국내 학생들과 외국인 유학생들 사이에 긍정적인 상호작용이 이루 어져 국내 학생들의 이문화 역량이 강화될 것이라는 전제를 기반으로 하고 있다. 그러나 대학과 정부의 단순한 외국인 유학생 유치 사업이 곧 성공적인 국제화로 이어졌다고 보는 것은 성급한 결론이며(Wright \& Lander, 2003), 실제로 캠퍼스 국제화가 그 기대처럼 국내 학생들에게 다양 한 혜택과 긍정적인 교육 경험으로 전환되고 있는지에 대한 논의가 필요하다.

\section{2. 캠퍼스 국제화에 대한 국내 학생의 인식을 다룬 선행연구 분석}

그 동안 고등교육 국제화에 대한 대다수의 연구는 국내외를 막론하고 외국인 유학생의 유학 경험과 이들의 인식에 주로 초점이 맞추어져 있었고, 국내 학생의 인식과 경험을 다루는 연구는 소수에 불과했다. 그러나 고등교육 체제 내에서 외국인 유학생이 상당한 비율을 차지하는 영미 권 국가(예: 미국, 영국, 호주 등)들에서는 외국인 유학생 유입 및 이와 관련된 경험에 대한 국내 학생들의 인식 연구가 최근 들어 활발하게 진행되어 왔으며 국내의 경우에서도 소수의 연구자 들을 중심으로 관련 논의가 점차 이루어지고 있다.

국내외 선행연구를 종합하여 살펴보았을 때 국내 학생과 외국인 유학생 간의 상호작용은 매 우 제한적인 범위에서 이루어지고 있어 온전한 의미의 학내 국제화가 실천되지 않고 있음을 유 추해 볼 수 있다. 해외 선행 연구들에서는 공통적으로 유학국의 자국 학생들은 외국인 유학생의 유입에 대해 대체적으로 중립적이거나 긍정적인 인식을 가지고 있으면서도 이들과의 상호작용 에 있어서는 무관심 또는 소극적인 태도를 보이는 이중성을 나타내거나(Peacock \& Harrison, 2009; Dunne, 2009; Spencer-Rodgers, 2001; Ward et al., 2005), 외국인 유학생 유입으로 인해

외국인 학생의 존재감을 노출시키고 특정 교수방법을 사용하여 국내 학생의 이문화 소통 역량을 향상, 셋 째, 국제적인 교육과정 제공, 넷째, 다양한 배경의 학생들로 이루어진 '국제교실'을 구축하여 내부 역동성 강화, 다섯째, IT기술을 활용하여 국가 간 경계 초월, 여섯째, 학생과 교직원의 세계적 시민의식 및 책임감 함양이 관련 내용이다. 
실질적으로 얻을 수 있는 이점에 대해서 회의적인 시각을 가지기도 하였다(UNITE, 2006). 한국 의 경우에서도 마찬가지로 국내 학생들과 외국인 유학생이 지속적인 교류를 하는 경우는 매우 드물었으며(이보경 외, 2013) Jon \& Kim(2011)의 연구에서도 한국 학생들의 외국 학생들에 대한 무관심을 지적한 바 있다. 이처럼 국내외 학생들 간의 활발한 상호작용이 이루어지지 않는 현상 에 대한 원인을 밝히고자 한 연구들은 주로 '차별의 관점'과 ‘경쟁과 위협의 관점'이라는 두 가지 의 흐름 속에서 이루어져 왔으며 이에 대한 결과는 각 국가의 맥락에 따라 상이하게 나타난다고 볼 수 있다.

1) 외국인 유학생에 대한 국내 학생들의 인식: 차별의 관점

첫 번째로 살펴 볼 내용은 외국인 유학생에 대한 국내 학생들의 인식을 차별의 관점에서 분석 한 연구들이며 이들의 대다수는 외국인 유학생의 출신배경에 따른 자국 학생들의 상이한 반응 과 인식을 다양한 이론적 관점을 통해 분석하였다. Harrison \& Peacock(2010)은 자문화중심주의 (ethnocentrism)의 관점에서 영국 학생들이 자신들과 언어와 문화가 유사한 타 유럽국가 출신, 또는 기타 영미권 국가 출신 학생들에게 동질성을 부여하며 이들을 비서구권 국가 학생들보다 더 선호하는 배경을 설명하였다. 또한 국내 학생들이 외국인 유학생을 차별하는 배경에는 언어 와 문화의 차이에서도 기인하였는데 이러한 상황은 특히 그룹 프로젝트과 같은 협력 학습 형태 에서 주로 발견되었다. 더 나아가 유학국의 국내 학생들은 외국인 유학생들의 낮은 수준의 언어 능력으로 인한 소통의 어려움은 물론 이들의 학업 능력도 열등한 것으로 인식3)하였고 이로 인 해 과제의 질이 떨어지는 데에 대한 불만을 가지고 있었다(Barron, 2006). 따라서 이를 방지하기 위해 외국인 유학생과 함께 협력하기를 의도적으로 회피하거나, 배제시키는 경향도 나타났다 (Ledwith \& Seymour, 2001; Volet \& Ang, 1998; Peacock \& Harrison, 2009). 이처럼 국내 학생 이 외국인 유학생을 출신배경, 언어능력, 학업 역량 등을 기준으로 행하는 '구분 짓기' 행태는 외국인 유학생으로 하여금 유학 국가 사회에서 소외되는데 결정적인 역할을 하고 있다.

한편, 이러한 외국인 유학생의 출신배경에 따른 차별적 인식이 한국에서는 비교적 상이하게 나타나고 있다. 한국 사회는 서구권 사회와 비교하였을 때 문화적 다양성이 낮고, 구성원들이 매우 동질적인 사회(김동수 외, 2011)로 이루어져 있기 때문에, 최근에 급속하게 증가한 캠퍼스 내에 외국인 유학생 규모에 대해 서구권 대학의 학생들보다 생소하게 인식할 가능성이 상대적 으로 높다. 특히 한국의 사회문화적 배경(식민지 경험, 한국전쟁, 미군정 등)은 그 동안 한국인들

3) 일부 선행연구 (예: Dunne, 2009)에서는 국내 학생이 외국인 유학생의 학업 역량을 더 높게 인식한다는 결 과도 있어 외국인 학생의 학업역량에 대한 국내 학생의 인식은 일반화하기 어렵다. 영미권 대학의 경우에 는 외국인 학생에게 더 높은 등록금이 부과되기 때문에 학업 태도에 영향을 미칠 수 있으며, 대학의 평판 과 명성에 따라 기관에 재학하는 외국인 유학생의 우수성에도 큰 편차가 나타날 가능성이 높기 때문이다. 
의 외국인들에 대한 고정관념을 고착화시키고 더욱 복잡하게 만드는 주요 요인으로 제기되어 왔고(김동수 외, 2011) 전반적으로 한국 사회에서 외국인에 대한 편견과 선호는 외국인의 인종, 민족, 출신국의 경제력과 같은 국제 질서에 따라 이분법적으로 구성되고 있다는 점을 선행연구 에서는 밝히고 있다(황미애, 2009; 임도경·김창숙, 2011). 이 중 국내 학생들과 외국인 유학생의 관계의 역동성을 분석한 Jon(2012)의 연구에서는 문화와 국가적 질서에 기반을 둔 신인종주의 (neo-racism theory)의 관점에 따라 국내 학생들과 외국인 유학생들의 교우관계에서 나타나는 역동성을 분석하였다. 그 결과 국내 학생들은 한국보다 경제적 수준이 높은 국가와, 서구권 출신 의 백인 학생들을 선호하는 경향이 나타났으며, 특히 외국인 유학생이 보유한 '언어적 자원(영 어)'은 학생들 간의 상호작용에 영향을 미치는 주요 요인으로 제시되기도 하였다. 그러나 해당 연구에서는 이러한 개인의 출신배경과 상관없이 외국인 유학생들의 유학 동기, 한국에 대한 호 감도와 같은 태도와 따라 국내학생들의 외국인 유학생들에 대한 선호도나 관심의 정도가 재구 성된다는 결과를 도출해 낸 바 있어 이문화 교우관계를 형성하는데 있어 '호혜’와 ‘수용'의 연결 고리의 중요성을 제시하기도 하였다. 또한 국내 학생들은 한국 대학에서 수학 중인 외국인 유학 생의 학업 역량과 관련하여, 해외 사례와 마찬가지로 국내 학생에 비해 외국인 유학생의 학업 역량 및 동기가 더욱 낮은 것으로 인식하고 있었다(Jon, 2012; 이보경 외, 2013).

2) 외국인 유학생에 대한 국내 학생들의 인식: 경쟁과 위협의 관점

외국인 유학생에 대한 국내 학생들의 인식을 분석한 또 다른 핵심 요소는 '경쟁과 위협의 관 점'이라고 할 수 있다. 선행연구에 따르면 외국인 유학생들의 유입에 따라 국내 학생들이 인식하 는 위협감을 지적하였으며 이는 외국인 유학생의 비율이 전체 학생의 일정 부분 이상을 차지하 게 되면 국내 학생의 외국인 유학생에 대한 부정적인 인식이 크게 증가한다는 연구 결과에서도 확인된 바 있다(Ward et al., 2005). 또한 국내학생들은 외국인 학생의 유입으로 인해 한정된 자 원(물리적, 재정적)을 두고 경쟁해야 하는 상황 속에서 상대적 박탈감 등(Anyanwu, 2004; Spencer-Rodgers \& McGovern, 2002)을 경험하고 있는 것으로 나타났다.

Harrison \& Peacock(2010)은 확장된 위협 이론(integrated threat theory)을 제시하며 외국인 유학생과 국내 학생과의 상호작용 과정에서 나타나는 4 가지 위협적 요소를 밝혀내었다. 이 중 첫 번째 요소는 현실적인 위협(realistic threat)으로, 이는 외국인 유학생의 유입으로 인해 학생들 간에 함께 공유하는 자원의 질(예: 학습의 질, 자원의 배분)이 실제적으로 떨어지거나 고갈되는 것에 대해 국내학생들이 느끼는 위협에 해당한다. 두 번째 요소인 상징적인 위협(symbolic threat)은 점점 증가하는 외국인 유학생 그룹의 이질적인 문화(예: 외국의 규범, 문화적 전통 등) 와 접촉하고 국내학생들이 그것에 압도되는 것에 대한 위협을 의미한다. 셋째, 집단 간 긴장 
(intergroup anxiety)은 외국인 유학생과 효과적으로 소통할 수 있는가에 대한 불안감 또는 두려 움으로 인해 생성되는 위협이며, 마지막으로 부정적인 고정관념(negative stereotyping)은 외국 인 유학생에 대해 형성된 일종의 부정적인 관점과 태도가 고착화되어 순환되는 것에 대한 위협 을 의미한다.

한편, 이러한 국내 학생들의 외국인 유학생에 대한 경쟁적 인식은 한국에서도 유사하게 나타 났으며 Jon \& Kim(2011)의 연구에서도 국내학생들은 교내의 다양한 자원이 외국인 유학생들에 게 편중되어 제공되고 있다고 인식하고 있어 상대적 박탈감을 느끼고 있다는 결과가 도출되기 도 하였다.

이처럼 기존의 연구들은 국내학생과 외국인 유학생의 상호작용에 영향을 미치는 다양한 요인 들을 분석하여 각각의 관점에서 해석하여 다양한 시사점을 제공하였다. 그러나 대다수의 연구는 특정 학위 과정(예: 학부생)과 전공 계열에 초점을 맞추어 이러한 인식이 국내 학생의 특성에 따라 어떻게 차이가 나타나는지에 대한 분석은 충분히 이루어지지 않았다는 한계점이 있다. 따 라서 본 연구에서는 국내 학생의 특성을 보다 면밀하게 고려하여 다양한 수준의 인식과 그 이면 에 내포된 배경 등을 탐색하고자 한다.

\section{III. 연구 방법}

\section{1) 연구 참여자}

본 연구는 캠퍼스 국제화가 전 학위과정 및 단과대학에 걸쳐 활발하게 이루어지는 캠퍼스에 서의 국내 학생의 인식과 경험을 관찰하기 위해 $\mathrm{A}$ 대학을 연구대상으로 선정하였다. $\mathrm{A}$ 대학은 국내 유수 대학 중 하나로 $\mathrm{A}$ 대학에 재학 중인 학생들은 치열한 입시 경쟁을 통해 이 대학에 입학했다는 자부심을 가지고 있으며 학내 문화 또한 경쟁적인 편이다. 또한, A대학은 2025년까 지 세계 10 위권 대학 진입을 목표를 가지고 있으며 이 중 대학의 국제화는 A대학이 설정한 목표 에 도달할 수 있는 핵심적 동인 중 하나라고 볼 수 있다. 따라서 $\mathrm{A}$ 대학은 국제화 체제를 강화하 기 위해 외국인 유학생 비율을 $30 \%$ 이상까지 확보하는 계획을 세웠다. 이를 위해 외국인 상시 지원 및 선발 시스템을 구축하였고, 해외에서 대학 설명회를 개최하였으며, 외국인 우수 대학원 생 지원 프로그램, 글로벌 초우수 인재육성 사업 등 장학지원 사업을 확충하여 실시하고 있다(출 처: A대학 홈페이지, 5개년발전계획). 또한 $\mathrm{A}$ 대학은 연구중심대학으로, 재적학생 기준 학부에 21,200 명, 대학원에 12,607 명이 등록되어 있어 대학원의 규모와 비중이 상당히 큰 편이다.

$\mathrm{A}$ 대학의 활발한 국제화 사업 결과 2005년에는 684명(학부 203명, 대학원 481명, A대학 통계연 
보)이었던 외국인 유학생 수가 급증하여, 2013년에는 총 1965명(학부 831명, 대학원 1134명, 대학 알리미)의 외국인 유학생이 정규 학위과정 중에 있다. 이는 재학생 기준으로 학부생의 $5 \%$, 대학 원생의 $10 \%$ 에 해당하는 수치다. A대학의 외국인 유학생 규모는 전국 기준 학부과정에서는 8 번 째, 대학원과정에서는 첫 번째로 크며(대학알리미, 2013) 대다수 국내 대학의 외국인 유학생이 학부 과정에 집중되어 있는 것과는 다르다고 볼 수 있다.

$\mathrm{A}$ 대학의 외국인 유학생들의 분포 현황을 계열별로 살펴보면 인문사회(48\%), 공학(21\%), 자연 과학(15\%), 의학(12\%), 예체능(4\%)에 속해있으며(대학알리미, 2013), 주요 출신국가로는 중국 $(33 \%)$, 미국(12\%), 일본(7\%), 캐나다(4\%), 베트남(4\%)으로(A대학 통계연보, 2013), 국적배경이 매 우 다양하고 비교적 균등하다는 점에서 국내 타 대학과의 차이를 보이는데, 이는 $\mathrm{A}$ 대학이 대학 교육 및 연구뿐만 아니라 대학 국제화에서도 선도적인 위치에 있음을 반영한다.

연구 참여자 모집 과정에서는 $\mathrm{A}$ 대학 재학생 중에서 외국인 유학생과의 교류 경험이 있는 학 부생 및 대학원생을 대상으로 하였다. 예비면담 결과, 외국인 유학생과의 교류 경험이 없는 국내 학생들은 외국인 유학생에 대한 인식 자체가 부재하거나 단편적인 경우가 많았기 때문에, 면담 의 양과 질을 위해 교류 경험이 있는 경우로 한정하였다. 그리고 성별, 학위과정, 단과대학 외에 해외체류경험이 있을 때 외국인 유학생을 긍정적으로 인식했다는 Jon(2013)의 결과를 고려하여, 해외체류경험을 연구참여자의 주요 특성에 포함시켰다. 또한 대학생활 경험의 양과 질을 고려하 여 학부생은 2 학년 이상, 대학원생은 석사 및 박사과정 2학기 이상으로 제한하였다. 그 결과 30 명의 지원자 중 최종적으로 24 명의 연구참여자가 확정되었다. 대략적인 분포를 살펴보면, 학위 과정별로 학부생 14 명, 대학원생 10 명이며, 성별로는 남자 16 명, 여자 8 명으로 구성되었다. 단과 대별로는 공대가 8 명으로 가장 많았고, 사회대 4 명, 경영대 3 명, 인문대 3 명, 자연대 3 명, 사범대 2 명, 생활대 1 명 순이었다. 해외체류경험은 경험이 없는 사람부터 1 개월 미만의 단기 여행 경험, 6 개월 및 1 년의 교환학생 경험뿐만 아니라 10 년의 장기체류까지 다양하게 분포하였다. 또한 교 내에서 제공되는 외국인 유학생과의 교류 프로그램 참여 여부를 분석에 참고하기도 하였다. 연 구 참여자에 대한 자세한 정보는 <표 $1>$ 와 같다. 
<표 1> 연구참여자의 특성

\begin{tabular}{|c|c|c|c|c|c|}
\hline 번호 & 참여자 & 성별 & 학위과정 & 단과대학 & 해외체류 여부 \\
\hline 1 & A & 여 & 학부4학년 & 경영대 & 1년 \\
\hline 2 & B & 남 & 학부4학년 & 경영대 & 1년 \\
\hline 3 & $\mathrm{C}$ & 남 & 학부4학년 & 경영대 & 6개월 \\
\hline 4 & $\mathrm{D}$ & 남 & 학부2학년 & 공대 & 8년 \\
\hline 5 & $E$ & 남 & 학부4학년 & 공대 & 1개월 \\
\hline 6 & $\mathrm{~F}$ & 남 & 학부4학년 & 공대 & 6개월 \\
\hline 7 & G & 남 & 학부4학년 & 공대 & 없음 \\
\hline 8 & $\mathrm{H}$ & 여 & 학부2학년 & 사범대 & 6년 \\
\hline 9 & I & 여 & 학부4학년 & 사범대 & 없음 \\
\hline 10 & J & 남 & 학부3학년 & 사회대 & 10년 \\
\hline 11 & K & 남 & 학부4학년 & 사회대 & 없음 \\
\hline 12 & $\mathrm{~L}$ & 남 & 학부4학년 & 사회대 & 없음 \\
\hline 13 & $\mathrm{M}$ & 남 & 학부1학년 & 인문대 & 1년 \\
\hline 14 & $\mathrm{~N}$ & 여 & 학부4학년 & 인문대 & 1년 \\
\hline 15 & $\mathrm{O}$ & 남 & 대학원 석사졸업 & 공대 & 2년 \\
\hline 16 & $\mathrm{P}$ & 남 & 대학원 석사과정 & 공대 & 없음 \\
\hline 17 & $\mathrm{Q}$ & 여 & 대학원 석사과정 & 자연대 & 1년 \\
\hline 18 & $\mathrm{R}$ & 여 & 대학원 박사수료 & 공대 & 1년미만 \\
\hline 19 & S & 남 & 대학원 박사과정 & 공대 & 1년미만 \\
\hline 20 & $\mathrm{~T}$ & 남 & 대학원 석사과정 & 사회대 & 1년미만 \\
\hline 21 & $\mathrm{U}$ & 여 & 대학원 석사과정 & 생활대 & 1개월 \\
\hline 22 & $\mathrm{~V}$ & 남 & 대학원 석사과정 & 인문대 & 없음 \\
\hline 23 & $\mathrm{~W}$ & 여 & 대학원 석사과정 & 자연대 & 1년미만 \\
\hline 24 & $\mathrm{X}$ & 남 & 대학원 석박 통합과정 & 자연대 & 6개월 \\
\hline
\end{tabular}

\section{2) 자료수집 방법 및 분석 절차}

본 연구는 특정 상황에 대한 개별 행위자들의 인식을 분석하기 위해 연구 참여자를 대상으로 면담을 실시하였다. 기존의 선행연구가 학부생에 한정되어 있고 단과대학별 차이를 보지 않았기 때문에, 본 연구에서는 연구참여자의 보다 다양한 배경에 초점을 맞추기 위해 연구참여자의 수 와 범위를 확대하여 반구조화된 면담을 개별적으로 실시하였다. 반구조화된 면담은 사전에 준비 한 질문지를 바탕으로 실시되므로 신뢰롭고 비교 가능한 질적 데이터를 얻을 수 있으며, 면담 횟수가 한정적이고 면담자가 다수일 때 가장 효과적이다(Bernard, 1988). 면담은 2014년 9월부터 10 월까지 이루어졌으며 연구 참여자 모집을 위해 학내 인터넷 커뮤니티에 연구 참여 안내문을 
게시하는 한편, 연구 참여자의 성별, 학위 과정, 단과 대학의 다양성을 꾀하는 최대변이표집 (maximum variation sampling)과 연구 참여자의 소개를 받는 눈덩이 표집법(snowballing)을 함 께 이용하였다.

연구진은 면담에 앞서 선행연구에서 사용된 이론 및 도출된 결과를 참고하여 면담용 질문지 를 구성하였다. 그리고 제작된 질문지 내용의 적합성을 검토하기 위하여 $\mathrm{A}$ 대학 학부생 및 대학 원생 6명을 대상으로 예비 면담을 실시 후 수정·보완을 거쳐 질문지를 완성하였다. 면담 시 사용 된 질문내용은 캠퍼스 국제화에 대한 전반적 인식, 학업 및 기타 학교생활에서 외국인 유학생들 과의 상호작용 경험과 이에 대한 인식, 대학 내 국제화 정책에 대한 견해 및 제언, 국제화 역량에 대한 인식 등을 자연스럽게 이끌어낼 수 있도록 구성하였다. 면담은 연구진 5인이 직접 실시하 였고 해당 대학의 강의실에서 1:1 개별면담 형태로 진행되었으며 평균 60 분 정도 소요되었다. 면담 내용은 참여자들에게 모두 동의를 얻어 녹음 후 전사되었으며, 참여자의 개인정보와 관련 된 내용은 모두 삭제한 뒤 각 참여자에게 식별번호를 부여하여 정리하였다.

분석방법으로는, 연구진 모두가 전사된 면담 자료를 반복하여 숙독한 후, 자료의 내용을 충분 히 숙지하도록 하였다. 그리고 개방 코딩(open coding) 방법을 사용하여 일차적으로 자료가 가지 고 있는 다양한 주제어와 개념들을 도출하고, 축 코딩(axial coding) 방법을 사용하여 개방 코딩 과정에서 분산된 자료들을 일련의 범주를 기준으로 구체화하여 재조직하여 자료를 분석하였다.

\section{IV. 연구 결과}

\section{1. 캠퍼스 국제화에 대한 이상과 현실 간의 괴리}

면담 결과 캠퍼스 국제화에 대해 대부분의 국내 학생들은 세계화 시대의 도래에 따른 자연스 러운 현상으로 받아들이고 있었고 상당 부분 수긍하는 행태를 보였다. 이들은 최근 들어 외국인 이주자, 다문화 가정, 외국인 고급인력 등의 증가로 한국 사회가 점차 다양성을 보이고 있어 현 재 캠퍼스의 국제화 현상도 그러한 변화에 따른 자연스러운 결과라고 인식하고 있었다. 그러나 이들은 '이상적'인 캠퍼스 국제화의 모습과 실제 학교생활을 통해 관찰하고 경험한 '현실'간의 괴리를 동시에 인식하는 양면성을 가지고 있는 것으로 나타났다. 특히 최근 들어 매우 빠른 속도 로 증가하는 외국인 유학생 규모에 대한 반발감과 이들을 충분히 지원하지 못하는 대학 내의 제도적 요인들을 비판적으로 인식하고 있었다. 특히 국내 학생들은 대학의 외국인 유학생 유치 배경과 목적이 외부적 환경, 즉 국제화 지수 향상을 통한 대학 평가 순위 올리기에서 비롯되었다 는 점을 지적하고 있었다. 
"지금 받는 인상은 대학 랭킹 올리려고 외국인을 너무 쉽게 받아주는 느낌을 받거든요. 그런데 너 무 아무런 대책 없이 외국인을 그냥 받기만 하는 것 같은 느낌이에요." (S/남/대학원 박사과정/공대)

"외국인 유학생을 유치하는 게 진짜 경쟁력 강화, 다양성 강화 이런 거보다 대학평가에서 순위 잘 나오게 하려는 게 아닌가..라는 문제의식이 있었어요." (K/남/학부4학년/사회대)

즉, 국내 학생들은 이론적인 측면에서는 더 많은 외국인 유학생이 한국 대학에서 수학할 경우 이들을 통해 새로운 세계, 문화, 언어 등에 노출되어 다양한 혜택이 부여될 수 있을 것이라고 인식하고 있었고, 실제 일부 학생들에게서는 그러한 긍정적인 사례도 발견 되었다. 그러나 대부 분의 국내 학생들은 국제화가 현장에서 실제로 잘 이루어지는지에 대해서 회의감을 보이고 현 재의 상황을 ‘과도기’라고 표현하였다. 또한 이들은 현재 교내에 재학 중인 외국인 유학생들의 대부분이 한국보다 경제 수준이 낮은 국가 출신인 점을 지적하였고, 이 때문에 그들이 자신들의 학업 및 연구에 큰 도움이 되지 않을 것이라고 지적한 사례도 있었다.

“주로 저희보다 좀 안 좋은 국가에서 오는 학생들이 많다보니까. 학업적인 면에서 그렇게 도움이 되지는 않는 것 같아요. 우리보다 더 나은 환경에서 좀 더 최신의 연구를 접해본 사람이 들어오면 저희는 좋은데 $\cdots$ 지금은 주로 우리한테 와서 우리 것을 배워서 보낸다는 취지로 유학생들을 많이 받는 것 같아요." (S/남/대학원 박사과정/공대)

마지막으로 국내 학생들은 대학 내에서 외국인 유학생과 한국어가 아닌 영어를 사용하여 상 호작용을 해야 한다는 부담감을 강하게 가지고 있었다. 일부 학생들에게는 이러한 부담감이 강 박관념으로 확장되어 의도적으로 외국인 유학생과의 상호작용을 회피하고 있는 경향도 보였다. 그러나 국내 학생들은 스스로의 외국어 능력(주로 영어능력)을 외국인 유학생들과의 상호작용 에 있어 장애물로 생각함과 동시에 외국인 유학생들의 부족한 한국어 능력을 비판적으로 인식 하기도 하였다. 즉, 한국이 영어공용어 국가가 아님에도 불구하고 영어 사용을 당연시하며 한국 어 학습을 소홀히 하는 일부 외국인 학생들에 대한 국내학생들의 불쾌감이 면담에서 일부 드러 났다.

"외국인들이 한국어를 아예 못하는 건 문제가 있다고 생각해요. 못하는 건 괜찮은데, 배울 생각 도 없는 건 문제가 있다고 생각해요. 한국어를 배울 생각이 없는 외국인들을 보면 한국에 왜 왔는지 이해할 수 없다고들 하죠." (Q/여/대학원 석사과정/자연대)

“어쨌든 한국에 왔으면 영어로 뭔가 해주는 건 호의이지 당연한 건 아니라고 생각해서. 여기가 미국은 아니잖아요." (M/남/학부1학년/인문대) 


\section{2. 외국인 유학생의 출신배경에 따른 인식 차이}

1) 한국으로의 유학동기에 대한 인식 차이

국내 학생들은 외국인 유학생들의 출신배경에 따라 그들의 유학동기를 다르게 인식하고 있는 경향을 보였다. 한국보다 경제적 수준이 낮은 국가에서 온 외국인 유학생들의 경우에는 '한국의 선진 기술, 학문을 배우기 위해' 유학을 왔다고 인식하는 반면 서양 학생들에 대해서는 ‘왜 굳이 이곳에 왔는지 모르겠다'라는 상반된 인식을 가지고 있었다.

“케냐에서 온 친구는 약간 19세기 때 인도나 이런데서 영국으로 유학 갔다 오듯이 케냐에서 온 친구는 '나는 여기서 많이 배워서 케냐로 돌아가야겠다' 이런 생각을 하고 있어요." (D/남/학부2학 년/공대)

“동남아 쪽 이런 애들 보면 저희가 미국학교 가는 식으로 조금 더 좋은 학교를 오고자 한 것 같 은 느낌을 받았고 서양 애들은 그냥 외국 나가서 생활하고 싶어서 온 게 아닐까 라는 생각을 했죠." (O/남/대학원 석사졸업/공대)

“서양 애들은 왜 굳이 여기까지 왔을까...그런 생각이 들어요. 거기에도 좋은 학교 많은데...굳이 왜 힘들게 여기까지 왔을까." (E/남/학부4학년/공대)

그동안 학생들의 이동은 주로 개도국의 학생들로부터 이루어졌으며 이들은 자국보다 상대적 으로 더 부유한 선진국을 유학지로 선택해왔다(안영진, 2008). 반면 최근에는 북미 및 유럽 지역 의 경기 침체와 개발도상국의 경제성장 및 적극적인 고등교육 국제화 정책에 따라 과거보다 더 많은 선진국 학생들이 개발도상국으로 이동하는 '역방향의 이동(reverse flow)' 또한 증가하고 있는 추세이다(Cantwell et al., 2009). 그러나 국내 학생들은 한국보다 경제적 수준이 더 낮은 국가 출신의 학생들이 유학을 온 계기에 대해서는 '당연하다'라는 반응을 보이는 반면에 북미 또는 유럽 지역 출신의 학생들이 한국을 유학선택지로 선택한 이유에 대해서는 '어리둥절'한 반 응을 보이고 있음을 알 수 있다. 이는 한국 대학, 더 나아가 아시아권 국가의 대학이 영미, 유럽 권 국가의 대학에 비해 상대적으로 낮은 경쟁력을 가지고 있다는 국내 학생들의 보편적인 인식 에 부분적으로 기반 해 있다고 볼 수 있다. 실제로 영국의 대학평가기관인 THE(Times Higher Education)이 발표한 2014 2015 세계대학순위에 따르면 세계의 100대 대학 중 영미, 유럽권 국 가의 대학이 89 개를 차지하고 있다. 또한 국내의 유수 대학에 재직 중인 교수진의 상당수는 해외 박사학위 소지자이며(이은혜, 2013), 한국 대학에서 사용되는 교재 및 이론의 대다수가 서구권에 서 수입되어(강명구.이상규, 2011) 교육되는 국내 대학의 특성으로 미루어 보아 이러한 학문적 
사대주의에 대한 국내 학생들의 일상적 체화는 서구권 학생들이 국내대학을 유학지로 선택한 현상을 충분히 이해하지 못하게 만든 요인으로 영향을 미쳤을 가능성이 존재한다.

\section{2) 학업 능력 또는 학업태도에 대한 인식 차이}

국내 학생들은 외국인 유학생의 출신배경에 따라 그들의 학업 능력이나 태도 또한 다르게 인 식하기도 하였다. 한국보다 경제적 수준이 더 낮은 개도국 출신 외국인 유학생들은 한국에서 더 많은 것을 배워서 돌아가고자 하는 확실한 동기가 있기 때문에 성실한 학업태도를 보이고 있다 고 인식하고 있었다. 또한 이들의 상당수는 자국정부 파견 장학생 또는 한국정부 초청장학생들 인 경우가 많았으므로, 학업 능력이 일부분 검증되었을 것으로 판단하고 있었다. 그러나 반대로 서구권 출신 학생들은 본국에서 상위권이 아닌 중하위권의 학업 역량을 가졌을 것이라고 유추 하고 있었으며 개도국 출신의 학생들에 비해 상대적으로 불성실한 학업태도를 가진 것으로 인 식하였다.

“우리 기준에서 선진국에서 온 학생들에 대해서는 약간... '그 나라에서 월등히 잘해서 온 거구 나' 라고 생각하기보다는 뭐랄까 '그냥 왔겠네' $\cdots$ 선진국 학생들에게는 그 나라에서 잘해서 왔다고 생각하지는 않아요." (W/여/대학원 석사과정/자연대)

“미주지역에서 온 친구들이랑, 다른 동남아나 중국 이런데서 온 친구들이랑 에티튜드가 좀 다른 것 같다고 해야 하나? 그러니까 미주권에서 온 애들은 아무래도 좀 모티베이션이 적고 정말 머리 써서 하기 보다는 이렇게 그냥, 편하게 하려는 게 있고, 또 좀 캠퍼스 밖으로 벗어나려는 경향이 있 는 반면에 동남아 친구들은 그런 게 굉장히 적어서 진짜 열심히 빡세게 해보자 약간 이런 게 있었 던 거 같아요. 그러니까 그쪽에서 오는 학생들은 공부에 진짜 더 관심이 있고 공부를 잘 하는 친구 들을 뽑는 것 같다는 생각이 들었어요. 문화차이인 것 같기도 하고" (N/여/학부4학년/인문대)

서구권 학생들의 학업 태도에 대한 부정적인 감정은 서양 학생들이 보이는 개인 중심 문화에 서 나오는 학업 태도(예: 수업시간에 늦게 오기, 중간에 갑자기 일어나 화장실 가기, 팀 과제 미 팅에 안 나오기 등)에 대한 불만에서 기인하는 경우가 많았다. 또한 일부 서구권 학생들이 한국 생활을 할 때 '영어’를 사용하는 것을 당연하게 인식하며, 영어를 잘 하지 못하는 교수자와 학생 에 대해 거리낌 없이 비판을 가하는 사례를 접하면서 이들에 대한 부정적인 감정이 더 커진 것 으로 보였다.

“외국인(서양) 학생들이 맨 뒤에 앉아서 f word를 쓰면서 욕을 하더래요. 교수님이 발음이 안 좋 으니까. 어떻게 저런 영어로 가르치냐면서 막 크게 이야기를 하더래요. 너무 예의 없는 느낌이었어 
요. 그런 이야기를 하는 데 제지를 하는 친구들이 없었다는 사실이 충격적이었어요." (A/여/학부4 학년/경영대)

이처럼 본 연구에 참여한 거의 모든 국내 학생들은 외국인 유학생을 위한 교내의 제도적 여건 (영어강의 포함)이 제대로 갖추어져 있지 않다는 점을 충분히 인식하고 있었고 이로 인해 외국 인 유학생들이 경험하는 어려움에 공감하고 있었다. 그러나 앞선 사례와 같이 외국인 유학생이 학교와 교수자를 전면적으로 비판하거나 무시하여 자신들의 자부심을 훼손하는 상황을 마주할 때면 불쾌감을 드러냈다.

한편, 국내 학생들은 외국인 유학생의 출신국가에 따라 학업능력과 학업태도에는 차이가 있 다고 인식하고 있었지만 이들의 전반적인 학업역량에 대해서는 출신 국가를 막론하고 국내 학 생들의 수준에 못 미치는 것으로 받아들이고 있었다. 특히 이공계열 학과에서는 학부 초반에 공 업 수학과 같은 과목에서 외국인 유학생이 국내 학생에 비해 크게 어려움을 겪고 있다고 밝히고 있었다.

"제가 학부생 수업에서 조교를 했었는데. 그 때 외국인 유학생들을 보면, 학업적인 측면에서 어려 움이 좀 많았어요. 수업이나 과제나 굉장히 어려워했어요... 대학교 입학하기 전에 학습한 배경, 고 등학교 때 교육 과정이 상당히 다르잖아요. 다른 교육과정을 받고 나서 입학하니까 한국학생에 비 해 어려움을 많이 느끼더라고요. 공대니까 주로 수학 문제 같은 거 풀 때도 기본적인 배경지식이 부 족하고. 그래서 많은 어려움을 겪더라고요. 그렇게 자꾸 뒤처지다보니까 열정도 떨어지고. 그러다가 학기 후반쯤 되면 수업도 잘 안 나오고." (S/남/대학원 박사과정/공대)

"사실 들어와서, 학문적으로 공부적으로 뛰어난 두각을 나타내는 외국인 유학생들을 만나 본 적 은 없는 거 같아요." (X/남/대학원 석박 통합과정/자연대)

반면 대학원 과정 학생들의 경우 외국인 유학생들이 가진 학문적인 측면에서의 국내 학생들 과는 다른 새로운 시각과 사고방식을 경험함으로써 도움을 얻을 수 있다는 점에 대해서는 긍정 적인 반응을 보이기도 하였다.

"수업이라기보다 문제에 접근하는 방식이라고 할까요. 저희 같은 경우에는 항상, 전공적인 건데, 이렇게 어떤 루트로 배우면 '항상 그 루트로 풀어야 되는 거 아니야?'라고 했는데, 예제를 띠워주자 마자 당연히 그렇게 풀겠지 했는데 다른 식으로 풀더라고요. 그런 거 되게 신선하다." (P/남/대학원 석사과정/공대) 
3) 출신배경에 따른 선호도의 차이

국내 학생들은 일부 선진국출신 외국인 유학생들의 상대적으로 낮은 학업 태도와 학업 능력 을 비판하기도 하였지만 여전히 개도국 출신 학생들보다는 선진국 출신, 특히 영미권 및 유럽 국가의 출신 학생들을 더 선호하는 경향이 나타났다. 이처럼 국내 학생들은 뛰어난 영어실력과 같은 일정한 '자원'을 갖춘 학생들을 선호하고 있었으며 이들과의 상호작용을 통해 자신에게 다 양한 방면에서 도움을 줄 수 있을 것으로 인식하고 있었다.

"일단 우리나라 사람들은 외국인 유학생이 들어온다고 할 때 가장 장점으로 꼽는 게 자기 학업에 도움이 되냐 아니냐에요. 제가 느낀 게 아시아 학생들은 항상 소외되고 그렇다보니 미국인을 가장 선호했었구요. 안 그러면 유럽 쪽 친구들. 그 친구들은 영어가 모국어가 아니어도 기본적으로 영어 를 잘하니까요. 아프리카나 아시아 이런 다른 쪽 영어 못하는 애들은 별로." (Q/여/대학원 석사과 정/자연대)

그러나 말레이시아, 인도와 같이 아시아권 국가이지만 영어를 공용어로 사용하는 국가 출신 의 학생들에게는 북미·유럽 지역 출신 학생들과 동일한 수준의 호감도를 나타내지는 않고 있었 다. 즉, 국내 학생들에게는 외국인 유학생이 보유하고 있는 '영어'라는 문화자본 외에도 해당 학 생들의 출신 국가의 경제적 수준과 인종적 배경에도 가치를 부여하고, 그를 바탕으로 일종의 선 입견과 차별적 견해를 지니고 있는 경우도 발견되었다. 특히 한국 학생들은 “외국인"을 이야기 할 때 주로 서구권 나라 출신의 서양인을 떠올리며, 한국인과의 유사한 외모를 가진 중국인이나 일본인은 외국인으로 잘 인식하지 않는 경향이 있다는 Jon(2011)의 결과와 외국인 유학생을 중 국인, 일본인, 그리고 다른 외국인 유학생으로 구분하며 그들을 대하는 태도와 심리적 거리가 다르게 나타난다는 전재은(2012) 연구의 결과와 비슷한 맥락을 확인할 수 있는 경우도 있었다.

“국적... 이런 걸 좀 먼저 따지는 거 같아요. 룸메가 외국인이라고 그러면 외국인이야? 중국인이 야? 이렇게 반응이 와요 사실. 유럽이나 미국사람이라고 하면 좀 뭔가 호감적인 반응이 나오고. 외 국학생이라는 카테고리 전체 하나 보다는 국적을 따져서 받아들이는 경향이 좀 있는 것 같아요." (W/여/대학원 석사과정/자연대)

\section{3. 동료보다는 불편한 손님으로 인식되는 외국인 유학생}

국내 학생들은 외국인 유학생들을 함께 공부하고 연구하는 동료이기에 앞서 일방적으로 도움 을 줘야하고 챙겨줘야 하는 '불편한 손님'으로 인식하는 경향이 강했다. 이러한 인식은 학위과정 과 전공계열에 따라서 차이가 나타났다. 
학위과정에 따라서는 학부생들의 경우에는 외국인 유학생들과의 교류 및 접촉이 주로 강의 수강과 과제 수행 중에 이루어지기 때문에 그룹 프로젝트와 같은 협력학습을 해야 하는 상황에 서 느끼는 번거로움이 더욱 가시적으로 나타났다. 가장 불편함을 느끼는 요소로는 언어적 차이 로 인한 진행상 능률의 감소였으며, 이러한 점이 새로운 경험을 통한 성장 가능성이라는 긍정적 인 측면보다는 과제를 수행하는 데 있어 불필요한 어려움이 생기고, 성과에 있어서도 부정적인 영향을 초래한다는 인식을 가진 학생이 더 많은 것으로 나타났다. 이에 일부의 학생들은 보다 효율적이고 효과적인 학습과정과 결과를 위해 외국인 유학생과 조별 활동을 하는 것을 회피하 고자 하는 경향도 보였다. 이처럼 외국인 유학생과의 조별 활동으로부터 나타나는 불편함은 학 부생들에게 공통적으로 찾아볼 수 있었다.

“일단 이해를 못하는 거에 있어서 설명을 해줘야 되고, ‘이렇게 이렇게 해야 한다'고 해줘야 되고, 혹시 또 과제를 나눠서 하는 과정에서 소통이 잘 안 될 수 있으니까. 같이 하기가 꺼려지고. "(I/여/ 학부 4 학년/사범대)

한편 대학원의 경우에는 대학원에서 나타나는 고유의 교육-연구 환경에서부터 비롯되는 불편 함의 차이가 발견되었다. 대학원에서의 교육과 연구는, 지도교수가 책임자로 있는 연구실과 같 은 소규모의 학문 커뮤니티가 형성되게 되며 주로 지도교수의 지도 아래 박사과정생이 중심이 되어 연구팀을 운영, 관련 업무도 분담하여 맡게 된다(김환석 외, 2008). 특히 이공계의 경우 대 부분의 대학원생은 인건비를 받는 연구 조교의 형태로 근무를 하게 되어 이들의 업무는 순수한 연구 활동뿐만 아니라 행정적 업무도 대거 포함되어 있다. 따라서 대다수의 대학원생들에게 대 학원은 단순히 공부를 하는 곳에서 더 나아가 '일'을 하는 공간으로 인식되고 있다. 이처럼 대학 원이 갖는 특수성 때문에 대부분의 이공계열 대학원생 면담자들이 인식하고 경험하는 외국인 유학생들에 대한 불편함은 주로 업무분담에서 비롯된 것으로 나타났다.

“학부 때는 외국인 친구들과 같이 노는 개념이잖아요. 그런데 대학원은 같이 일을 하는 개념이거 든요. 아무래도 외국인들이 할 수 없는 일(행정적)인 경우에는 제가 제 시간을 투자해서 해줘야 할 게 너무 많은거에요. 행정일이라든지 샐러리라든지 서류를 꾸며야 할 때, 한국말을 하나도 못 읽으 니까 그 친구들한테 맡길 수가 없거든요. 그런 일은 연구실에서 한국인들이 다 떠맡고 있어요. 어떻 게 고쳐질 수 있는 방법이 없어요. 그 친구들이 한국어를 배우지 않는 이상. 어쩔 수 없으면서도 이 건 역차별 아닌가 싶어요." (Q/여/대학원 석사과정/자연대)

"외국인 유학생이 있다고 영어를 많이 하고 실력이 느는 그런 점보다는 그들이 있어서 일이 느려 지는 불편함이 더 크니까. 그 불만이 크죠." (S/남/대학원 박사과정/공대) 
따라서 상당수의 연구실에서는 업무 분담 과정에서 외국인 유학생을 배제하는 경향도 나타났 다. 또한 국내 학생들은 본인들이 감수해야 할 업무량이 외국인 유학생이 들어옴으로 인해 더 많아지는 것으로 인식하는 것으로 나타났고 일부 학생들은 이에 대한 형평성 문제를 제기하기 도 하였다.

“(교수님이) 주로 자대생을 위주로 시키기 때문에 외국인 유학생에게 딱히 많이 일을 분담시키시 지는 않는 것 같아요. 일 분배에 대해서는 외국인 유학생과 말이나 언급조차 없어요. 그냥 그러려 니." (U/여/대학원 석사과정/생활대)

또한 일부 외국인 유학생들은 출근을 제대로 하지 않거나 업무시간을 제대로 지키지 않는 사 례도 있어 이를 국내 학생들에게 부정적인 인식을 강화시키는 경향도 있었다. 국내 학생들은 한 국의 대학원 문화가 권위적이고 위계적임을 인정함과 동시에 이러한 문화에 외국인 유학생들이 좀 더 노력을 통해 맞추어 주기를 희망하고 있었다.

“어떤 분이 좀 자기가 선배니까 명령조로 교수님 안 가셨으니까 할 일없어도 엉덩이 붙이고 앉아 있으라고, 자리지키라고 $\cdots$ 그걸 진짜 이해 못해요. 할 일 없으면 집에 가서 개인의 스케줄을 소화하 면 되지 왜 거기서 시간을 때우고 있냐 정말 비효율적이다 이런 애기를 하거든요. 그런데 결국엔 그 분들이 받아들이는 게 더 빠를 것 같다고 생각해요. 한국에서는 어쩔 수 없는..” (W/여/대학원 석 사과정/자연대)

"외국인들이 생각하는 게, '내가 프로젝트를 해내면 되는거지. 왜 필요 없는 시간까지 있어야 하 나고 생각하는 거 같아요. 교수님들은 첨엔 나오라고 했는데 그때도 본인이 일이 있다고 몇 번 늦 게 오거나 안 나오거나 했어요. 연락도 안하고. 교수님이 걱정이 돼서 기숙사로 찾아가보라고. 일주 일정도 연락이 안됐거든요. 결국 찾아갔더니, 왜 내 사생활까지 침해하느냐고." (R/여/대학원 박사 수료/공대)

한편, 전공계열에 따라서도 외국인 유학생과 함께하는 것에 있어 국내 학생들이 느끼는 불편 함과 번거로움은 그 정도가 다르게 나타났다. 이공계열에서는 수업내용에서 세계적으로 통용되 는 수학 공식이나 용어가 차지하는 비율이 높아 수업시간이나 학습에서 국내 학생들이 외국인 유학생들이 함께 공부하는데 있어 언어적인 측면의 어려움이 상대적으로 덜한데 반해 인문사회 계열에서는 수업시간과 과제수행 모두에서 자신의 생각을 심도 깊고 원활하게 표현하고 서로 의견을 나누는 언어적인 능력이 더욱 중요하게 인식되고 있었다. 
죠." (T/남/대학원 석사과정/사회대)

"(공대에서도) 팀플이 있긴 한데. 서로의 의견을 교환하거나 그런 특성의 수업이 아니니까. 수업 자체에서 용어 같은 게 다 영어니까. 공대라는 게 외국에서의 교재를 많이 사용하니까 (이미 국제화 가 됐죠)." (F/남/학부 4 학년/공대)

\section{4. 입학기회, 자원 배분에 대한 상대적인 박탈감}

국내 학생들은 대학이 외국인 학생들에게 상대적으로 더욱 많은 혜택을 주고 있다고 인식하 며 그에 따른 박탈감을 느끼는 경우도 발견되었으며 이는 기숙사, 장학금, 입학 경쟁 등과 같은 다양한 영역에서 나타나고 있었다.

외국인 유학생의 한국 유학동기를 살펴본 선행연구에 따르면 장학금과 같은 재정 지원이 주 된 동기가 되고 있음이 지적된바 있다(이민경, 2012; 송유리나, 2013; 임희진, 2014). 이 중 임희진 (2014)의 연구에서는 A대학에 재학 중인 약 $65 \%$ 의 외국인 유학생들은 최초 한국이 아닌 타국을 유학지로 희망하였지만 결국 한국 정부와 대학들이 제공하는 재정 혜택을 통해 한국을 최종적 으로 선택하였다는 결과를 제시하였다. 이러한 재정 유인책이 외국인 유학생 유입에 미치는 영 향에 대해서는 면담에 참여한 국내 학생들도 대부분 인식하고 있었다.

"그런 장학금이 그 외국학생들에게 어떤 작용이 하는가가 중요한 것 같아요 예를 들어서 별로 올 생각이 없었는데 혜택이 너무 좋으니까 한국에서 몇 년 살 겸 그냥 학교도 다니고 해야겠다." (O/남/대학원 석사졸업/공대)

“어디서 듣기로는 외국인 유학생을 유치할 때 우리가 기숙사도 주고 뭐도 주고 다 줄 테니까 몸 만 와라." (P/남/대학원 석사과정/공대)

국내 학생들은 적극적인 재정 유인책을 통한 외국인 유학생의 유치는 결코 대학의 경쟁력과 국내 학생들의 역량 강화에 도움이 되지 않으며, 비용대비 효용성이 떨어진다고 인식하고 있었 다. 외국인 학생에 대한 혜택을 늘리는 것보다는 오히려 A대학의 국내 학생에 대한 지원을 늘리 는 것이 선행되어야 한다는 문제의식을 제기하기도 하였다.

“학교가, 우리 학생들에게 좀 투자를 많이 해줬으면 좋겠어요. 장학금도 좀 많이 주고." (X/남/대 학원 석박 통합과정/자연대) 
게다가 국내 학생들은 '외국인이기 때문에' 더 쉽고 빨리 제공되는 대학의 지원책이 많다는 것에 거부감을 느끼는 경우가 많았는데, 그 대표적인 예로 기숙사와 같이 한정된 공간을 두고 경쟁해야 하는 것에 대한 불만을 들 수 있었다. 현재 A대학에는 지방 출신 학생들이 $40 \%$ 정도로 상당수 분포하고 있는 것으로 나타나고 있었는데(문화일보, 2014.8.26.), 서울 소재 대학들은 면 적이 좁고 땅값이 비싸 기숙사 제공률이 현저히 낮아 국내 학생들의 기숙사 입사 혜택이 기본적 으로 낮아질 수밖에 없다. 게다가 대학생들을 대상으로 한 서울 시내 숙박 시설에 대한 기본적인 비용이 높기 때문에, 지방 대학생들의 주거 문제는 사회적 문제로까지 대두되고 있는 실정이다 (한국대학신문, 2014.10.7.). 이러한 상황에서 외국인 유학생들에게 기숙사 입사를 우대해 주는 정책은 $\mathrm{A}$ 대학의 지방 출신 국내 학생들에게 상대적으로 큰 박탈감을 줄 수 있다.

“옛날 같은 경우에는 기숙사 거의 다 살고 있고 지방학생에 대한 배려가 되게 좋았는데. 어느 순 간부터 기숙사에서 다 쫓겨나고, 심지어 대학원생도 쫓겨나고 이런 상황이 되니까 저는 그런 거에 대해서 부정적이에요." (M/남/학부1학년/인문대)

"기숙사 같은 걸 배정할 때도 외국인들은 무조건 넣어주는데 그럼 그만큼 일반 학부생들이 들어 올 곳은 너무 적어지지 않냐." (I/여/학부4학년/사범대)

또한 국내학생들은 입학전형과 영어 강의에서의 경쟁 등 눈에 보이지 않는 자원에 대한 경쟁 에 있어서도 상대적으로 박탈감을 가지고 있는 것으로 나타났다. 면담에 참여하는 다수의 국내 학생들은 외국인 유학생의 입학 전형에 대해, 과연 $\mathrm{A}$ 대학에 들어올 실력을 갖춘 학생을 뽑고 있는가에 의문을 제기하고 있었다. 국내 유수 대학 중 하나인 A대학은 국내 학생이 들어오기에 는 굉장히 어렵고 까다로운 편인데 반해, 외국인 유학생에게는 상대적으로 쉽게 개방되어 있는 학교로 생각되고 있었다.

“외국인 특별전형에 대해서 조금 더 엄격하게 선발해야 된다고 생각해요. 외국인 특별전형 친구 들도 많은데 대부분 열심히 하지만 안하는 애들도 있는 것 같고, 한국 학생들보다 A대학교 들어오 기가 쉬운 것 같아서 $\cdots$ 그런 점을 좀 더 엄격히 하면 좋을 것 같아요." (Q/여/대학원 석사과정/자 연대)

\section{$\mathrm{V}$. 논의 및 결론}

현재 한국의 정부와 대학들은 2004년 Study Korea Project의 도입을 필두로, 외국인 유학생들 을 유치하는데 많은 노력을 기울여왔으며 그 결과 단기간에 외국인 유학생 유입의 양적 팽창이 
라는 성과를 이루어냈다. 그러나 그동안 우리 정부와 대학은 많은 수의 외국인 유학생을 유치하 는 데 초점을 맞춘 나머지, 실제 대학 현장에서 이러한 변화에 가장 큰 영향을 받고 있는 국내 학생들이 어떠한 관점과 인식을 가지고 이를 받아들이고 있는가에 대한 고민은 충분히 이루어 지지 않고 있었다. 따라서 본 연구에서는 캠퍼스의 구성원이 다양해지는 현상, 즉 캠퍼스 국제화 가 실제 국내 학생들에게 어떠한 의미와 영향을 미치는지에 대한 논의를 국내 학생들의 관점에 서 살펴봄으로써 분석하고자 하였으며 다음은 본 연구에서 도출된 주요 결과와 그와 관련된 논 의이다.

분석 결과 국내 학생들은 공통적으로 캠퍼스 국제화를 통해 주어지는 긍정적인 부분보다 국 제화의 이상과 현장에서의 괴리, 불편, 또는 상대적 박탈감과 같은 부정적인 측면을 더 크게 인 식하고 있었다. 이러한 캠퍼스 국제화의 이상과 현실 간의 괴리에 대한 주요 원인으로는 대학이 국제화를 통해 실질적인 대학의 내실과 학생들의 교육 역량을 강화시키려는 목적보다는, 국내외 대학 순위평가와 같은 외부적 환경에 의해 의도적으로 외국인 유학생의 규모를 증가시킨다는 점(Jon \& Kim, 2011; 박성훈·송유철, 2013)에서 찾아 볼 수 있다. 외국인 유학생의 유치 목적 및 배경은 각 국가가 처해져 있는 환경과 특성에 따라 상이하며 한국과 같은 신흥 유학생 유치 국 가의 경우에는 실질적인 교육적 목적보다는 외국인 유학생 유입을 통한 대학평가순위, 대학 평 판 강화 등과 같은 외부환경이 상대적으로 더욱 밀접하게 연계되어 있다(Altbach, 2007).이러한 맥락 속에서 구현되는 국제화는 국내 학생들로 하여금 현장에서 더욱 큰 괴리감을 느끼게 만드 는 주요 요인이 될 수 있다.

다음으로, 국내 학생들은 캠퍼스 국제화를 통해 유입되는 외국인 유학생들을 그들의 출신배 경에 따라서 차별적으로 선호하고 있었다. 앞선 선행연구에서 영국의 학생들은 외국인 유학생들 을 인식하는 데 있어 자신들과 국적은 다르지만 같은 지역-문화권 출신의 학생들을 자신들과 동질적 특성을 가진 구성원으로 간주하여 선호하는 경향을 보였다(Peacock \& Harrison, 2009). 이와 같은 맥락이라면, 한국 학생들 또한 우리와 유사한 문화와 인종적 배경을 가진 아시아 출신 외국인 유학생을 더 선호해야 할 것이다. 그러나 흥미롭게도 한국 학생들은 상대적으로 동질적 특성을 가진 같은 아시아 국가 출신의 학생들보다는 문화와 사회적 구조가 매우 다른 서구권 출신의 외국인 유학생을 그들이 가진 경제-문화적 배경에 따라 차별적으로 선호하고 있었다. 이 는 Jon(2012)의 연구에서 제시하였던 신인종주의적 관점과 연결될 수 있는 부분이며, 프란츠 파 농(1952)이 유색 인종이 가지는 열등의식은 식민지를 경험한 국가에서 나타나는 인종주의와 식 민주의의 결합에서 오는 필연적인 양상이라고 설명한 부분과도 연결될 수 있다. 더 나아가 국내 학생들은 자신에게 실질적인 이득(예: 언어)을 제공할 수 있는 요건을 갖춘 외국인 유학생을 선 택적으로 선호하는 경향을 보이는 특징을 나타냈다. 이처럼 국내 학생과 외국인 유학생 간의 상 호작용에서 '영어'가 매개 역할을 하는 현상은 한국에서 뚜렷하게 나타나는 특징이며 이는 영어 
가 한국 사회와 글로벌 고등교육의 헤게모니에서 차지하는 역할과 위상과 직결된다고 볼 수 있 다(최수정, 2013; 최샛별, 2003).

한편, 외국인 유학생의 출신배경에 따라 형성되는 선호도와는 달리, 국내 학생들이 외국인 유 학생들의 학업동기와 태도를 인식하는 데에는 또 다른 양상이 나타났다. 즉, 국내 학생들이 외국 인 유학생의 출신배경에 따라 일차적으로 구성하게 되는 일종의 선호도는 고정적이거나 영구적 인 특성을 가지고 있는 것이 아니며 이는 외국인 유학생이 한국에서 대학 생활을 하며 나타내 보이는 그들의 학업 동기와 태도에 따라 재구성된다고 나타나 Jon(2012)과 Jon \& Kim(2011)의 연구결과와 유사한 결과를 보였다. 즉, 국내 학생들은 한국보다 경제적 수준과 교육적 수준이 높은 국가 출신의 학생들, 특히 일부 서구권 학생들의 태만한 학업태도와 학업 능력을 부정적으 로 인식하고 있었으며, 이는 국내 학생들로 하여금 서구권 학생들의 학업 능력을 폄하하며, 자신 들의 학업을 방해하는 열등한 요소로 간주하게 되는 주요 동인이 된다는 점을 찾아볼 수 있었다.

다음으로, 국내 학생들은 외국인 유학생들을 함께 공부하고 연구하는 동료이기에 앞서 일방 적으로 도움을 주고 챙겨줘야 하는 ‘불편한 손님’으로 인식하고 있었는데, 이러한 인식에는 국내 학생의 특성(전공계열, 학위과정)에 따라 일정한 차이가 존재하는 것으로 나타났다. 특히 국내 학생들은 전반적으로 외국인 유학생들의 낮은 학업 역량과 원활하지 않은 한국어 구사력 등으 로 인해 이들과의 협업에 어려움을 표현하였고, 이는 곧 외국인 유학생과의 협업을 회피하거나 배제하는 현상으로 이어지기도 하였다. 이러한 배제 현상은 비단 한국에서만 나타난 것이 아니 라 다수의 해외 연구에서도 공통적으로 확인된 바 있다(Peacock \& Harrison, 2009; Barron, 2006; Volet \& Ang, 1998). 이처럼 언어 소통의 어려움이 학생들 간의 상호작용에 미치는 영향은 대부 분의 선행연구에서도 공통적으로 나타나지만, 한국의 대학에서는 영미권 국가와 달리 외국인 유 학생이 '영어'와 '한국어'를 동시에 구사해야 하는 구조적 특수성을 지니고 있어 이러한 특성이 학생들의 상호작용에 미칠 수 있는 영향은 상당히 클 가능성이 있다. 한편, 국내 학생들이 인식 하는 어려움의 정도는 국내 학생의 전공계열의 특성에 따라 상이하였는데, 언어적 소통 능력이 더욱 크게 요구되는 인문사회계열에서는 어려움의 크기가 상대적으로 큰 것으로 나타났다. 이공 계열의 경우의 학생들은 범세계적으로 통용되는 일반적인 학술용어, 공식 등의 사용으로 인해 어려움에 대한 인식의 강도가 상대적으로 낮은 것으로 나타나 전공 계열에 따른 인식의 차이가 존재하는 것으로 나타났다.

또한 학위과정에 따라서도 느껴지는 '불편함'의 인식 수준도 다르게 나타났다. 학부 과정의 경우에는 그룹 프로젝트와 같은 협력학습 경험으로부터 불편함의 인식이 형성되어 외국인 유학 생을 배척하는 현상으로 이어졌다면, 대학원의 경우에는 연구실에서의 업무 분담에 따른 어려움 및 문화적 차이로 인한 갈등적 상황으로부터 형성된 것으로 나타났다. 한국 대학의 문화는 유교 적 뿌리에 근거하며, 여기에 대학이 기본적으로 가지는 관료제적 특성이 가미되어(Shin, 2012) 
매우 강한 위계적 구조가 구성원 간의 관계를 지배(권인숙 외, 2010)하는 것이 특징이며, 이러한 문화는 대학원 과정에서 더욱 가시적으로 나타나게 된다. 특히 대학원생들은 본연의 학업, 연구 활동 외에도 다양한 행정적인 업무를 병행하고 있다는 점이 특징이다. 그러나 이러한 국내 대학 원 고유의 구조에 외국인 유학생들이 쉽게 적응하지 못하거나, 거부반응을 보일 때 국내 대학원 생들이 느끼는 부담과 그에 따른 부정적 인식 또한 강화되는 것으로 나타났다. 특히 이러한 상황 에서 외국인 유학생들 중에서도 서구권 출신의 학생들과의 마찰이 상대적으로 잦게 나타났는데, 이는 동양 문화권이 집단주의적 성향이 높은 특성을 가지고 있는 반면에 서구 사회의 문화적 기원은 개인주의에 뿌리를 두고 있기 때문으로(Wright \& Lander, 2003) 해석될 수 있다. 따라서 학생들 사이에서 나타나는 다양한 갈등 상황(업무분배, 조 편성 등)을 완화시키기 위해서는 교수 자의 역할이 매우 중요할 것으로 예상되며, 교수자는 학생들이 처한 상황과 환경을 정확하게 파 악하고, 관련된 갈등 상황을 조절하는 역할을 할 수 있는 역량이 점차 더욱 필요할 것이다. 한편, 국내 학생들의 해외 체류 경험 또한 캠퍼스 국제화에 대한 인식에 영향을 미칠 것으로 가정하였 으나, 분석 과정에서 두드러지는 차이를 발견하지 못하였다. 이는 학생들의 외국 거주 경험특성 이 외국인 유학생과의 상호작용 및 접근성을 강화하는 데에는 영향력을 미칠 수 있지만 실제 이들이 캠퍼스 국제화 자체에 대해 가지는 인식에는 거주 경험이 없는 학생들과 비교했을 때는 큰 차이가 없을 수 있음을 시사한다.

마지막으로, 국내 학생들은 대학이 외국인 유학생들의 유치를 용이하게 하기 위하여, 입학전 형과 자원배분(예: 기숙사, 장학금)등에 있어 보다 우호적인 정책을 펼치고 있어 상대적인 박탈 감을 경험하였다는 사례가 분석되어, Jon \& Kim(2011)의 연구와 유사한 결과가 도출되었다. 최 근 들어 대학(원)생의 주거 문제와 등록금 문제는 한국 사회에 전반적으로 빠르게 확산되어 있 는 사회적 문제이며, 이러한 국내 학생들의 상대적인 박탈감은 타 대학에서도 상당 부분 공통적 으로 나타날 수 있을 것이다. 이처럼 국내 학생들이 외국인 유학생들의 유입으로 인해 한정된 자원에 대한 경쟁이 더욱 심화된다고 인식하는 현상은 Peacock \& Harrison(2009)의 연구에서 제시한 통합위협이론(integrated threat theory)에서 제시한 '현실적 위협' 부분과 연결 지어 해석 될 수 있다. 또한 일부 연구 참여자들은 대학에서의 영어 사용, 외국인 유학생 증가로 인한 구성 원의 다양화 등을 이유로, 자신들의 대학에 '한국적' 특성이 훼손될 수 있다는 우려를 나타냈는 데, 이는 해당 이론에서 제시한 '상징적 위헙'과 연결된다고 볼 수 있다.

이처럼 국내 학생들이 캠퍼스 국제화를 바라보는 부정적인 인식과 관련된 경험은 다양한 범 위의 사회적, 문화적 그리고 제도적 영역으로 인해 발생하고 있음을 알 수 있다. 우리나라 정부 와 대학이 캠퍼스 국제화를 통한 성공적인 '학내 국제화'를 구현하기 위해서는 구성원들 간의 충분한 소통과 그에 따른 공통된 목표의 합의가 이루어지는 것이 매우 중요하다고 볼 수 있다. 그러나 본 연구의 결과를 기준으로 살펴보았을 때 현재의 캠퍼스 국제화는 정부와 대학 그리고 
이를 둘러싼 외부환경이 중심이 되는 하향식 구조로 이루어지고 있고 실제 국내 학생들의 인식 과 경험은 충분히 반영되어 있지 않다고 볼 수 있다. 따라서 향후 대학 기관과 정부에서는 외국 인 유학생 유입이 국내 학생들에게 미칠 영향을 보다 세밀하게 고려하여 그에 따른 문제를 해결 할 수 있는 다양한 장치를 마련할 필요가 있을 것이다. 예를 들어 본 연구 결과에서 나타난 것과 같이 국내 학생들이 경험할 수 있는 역차별적인 상황을 완화시킬 수 있는 노력이 이루어질 필요 가 있다. 특히 외국인 유학생의 입학전형 강화는 국내 학생들의 박탈감 완화뿐만 아니라 외국인 유학생의 학업태도, 학업 능력 등과 관련된 질 관리 해결책과도 직간접적으로 연결된다고 할 수 있다. 또한, 외국인 유학생의 낮은 한국어 구사능력이 학생들 간의 상호작용의 질을 결정짓는 핵심적인 요소로 작용한다고 보았을 때, 대학기관과 정부는 한국 대학 입학, 졸업 시 외국인 유 학생에게 요구되는 한국어능력 기준을 보다 강화하고 입학 후에도 지속적으로 한국어 능력을 향상시킬 수 있는 제도적 지원을 제공할 필요가 있을 것이다. 그러나 교육부는 최근 이공계열을 시작으로 외국인 유학생의 한국어능력시험(TOPIK) 입학 기준을 완화하는 방안을 허가하였는데, 이는 학생들 간의 상호작용의 질을 더욱 저하시킬 수 있는 요인으로 이어질 수 있어 재고될 필 요가 있을 것이다.

본 연구는 그동안 큰 주목을 받지 못했던 외국인 유학생 유입에 대한 국내 학생들의 인식을 포괄적으로 분석하여 기초적이고 의미 있는 단서를 제공했다고 할 수 있다. 그러나 본 연구의 결과에는 연구중심대학의 특성은 물론, $\mathrm{A}$ 대학이 자체적으로 가지고 있는 고유의 특성이 반영되 어 있을 수 있다. 따라서 대학 기관이 가지는 특성을 고려하여 연구 범위가 후속연구를 통해서 확장된다면, 국내 고등교육의 캠퍼스 국제화에 보다 풍부한 논의와 시사점을 제공할 수 있을 것 으로 판단된다. 또한 본 연구에서는 캠퍼스 국제화에 대한 국내 학생들의 전반적인 '인식'에 초 점을 맞추었기 때문에, 후속 연구에서는 여기에서 더 나아가 국내 학생들이 외국인 유학생과 접 촉하며 얻게 되는 다양한 경험과 그 효과를 보다 면밀히 살펴볼 필요가 있을 것이다. 


\section{참고문헌}

강명구, 이상규(2011). 이론과 현실 사이에서: 부르디외 이론의 적용과 변용, 혹은 생성. 한국방 송학회 학술대회 논문집. 2011(11), 17-23.

권인숙, 나윤경, 문현아(2010). 한국과 대만의 대학문화 비교. 여성학논집, 27, 145-183.

김동수, 김도환, 정태연(2011). 외국인에 대한 한국 대학생의 인식: 6개 외국인 집단을 대상으로.

한국심리학회지:사회및성격, 25(1), 1-23.

김환석, 김동광, 조혜선, 박진희, 박희제(2008). 한국의 과학자사회: 역사, 구조, 사회화. 서울:

궁리.

나임순(2006). 외국인 유학생의 문화적응 스트레스와 생활 스트레스에 미치는 영향. 한국비영리

연구, 5(2), 159-197.

노경란, 방희정(2008). 한국대학생과 국내체류 외국대학생 간에 인종에 대한 명시적 및 암묵적

태도의 차이. 한국심리학회지 사회및성격, 22(4), 75-92.

대학알리미(2014). www.academyinfo.go.kr

문화일보(2014.8.26.). A대 신입생 61\%가 수도권...쏠림'심화.

http:/ /www.munhwa.com/news/view.html?no=2014082601071127158002

(2014.10.12.)

박성훈, 송유철(2013). 한국고등교육의 국제화에 대한 정부와 교육기관의 대응전략 연구. 경상논

총, 31(2), 29-43.

박소진(2013). 한국대학과 중국인 유학생의 동상이몽: 서울과 지방 소재 사립대학 비교. 한국문

화인류학, 46(1), 191-234.

송유리나(2013). 외국인 유학생의 대학 선택 영향 요인 분석. 석사학위논문, 고려대학교.

안영진(2008). 세계의 유학생 동향과 국제적 이동 특성. 국토지리학회지, 42(2), 223-236.

엄상현, 변기용(2012). 고등교육 국제화에 대한 국내외 연구동향 분석. 교육문제연구, 42,

123-155.

이민경(2012). 지방대학 외국인 유학생들의 유학동기: A대학 아시아 유학생들의 한국 유학 선택

과 그 의미를 중심으로. 한국교육학연구, 18(2), 177-201.

이보경, 김은정, 김은경(2013). 국제화교육에 대한 대학생 인식조사를 통한 우리나라 대학의 국 제화 교육 실태와 개선 방향 탐색. 한국교양교육학회 학술대회 자료집, 2013(6), 317-328.

이은혜(2013). 대학교원의 박사학위 취득대학과 임용대학 간의 구조적 관계 분석. 석사학위논문, 
서울대학교.

임도경, 김창숙(2011). 대학생들의 다문화 인식 및 선행요인에 관한 연구: 사회적 거리감, 외국인 이미지, 한국인 인정조건을 중심으로. 커뮤니케이션학연구 19(1), 5-39.

임수진, 한규석(2009). 중국인 유학생이 겪는 심리적 부적응에 미치는 사회·심리적 요인 분석. 한국심리학회지 학교, 6(3), 413-427.

임희진(2014). 외국인 유학생의 진로계획 영향 요인 분석: 서울대학교 재학생을 중심으로. 석사 학위논문, 서울대학교.

전재은(2013). 한국 대학생의 이문화 역량에 대한 이해와 행동 반응. 아시아교육연구, 14(3), 231-259.

전재은, 장나영(2012). 국내 중국인 유학생의 한국 학생과의 교우관계: 중국인 유학생의 경험과 인식. 한국교육학연구, 18(1), 303-326.

최샛별(2003). 한국 사회에서의 영어실력에 대한 문화자본론적 고찰: 대학생들의 영어학습실태 와 영어능력자에 대한 인식을 중심으로. 사회과학연구논총, 11, 5-21.

최수정(2013). 영어의 사회문화적 힘과 이에 대응하는 한국 대학생들의 태도에 대한 고찰. 현대 영어영문학, 57(4), 265-291.

한국대학신문(2014.10.7.). 대학기숙사 수용률 36\% '태부족'.

http://news.unn.net/news/articleView.html?idxno=139682 (2014.10.17.)

황미애(2009). 외국인의 사회경제적 지위에 따른 학생들의 차별적 태도 연구. 시민교육연구, $41(3), 205-226$.

Altbach. G., \& Knight, J. (2007). The Internationalization of Higher Education: Motivations and Realities, Journal of Studies in International Education, 11(3), 290-305.

Anyanwu, C. (2004). Challenges and prospects of internationalisation in Australia's GO8 and universities of technology. In International Education: The path to cultural understanding and development. Paper presented at 18th IDP Australian International Education Conference (Australia), Sydney.

Barron, P. (2006). Stormy outlook? Domestic students' impressions of international students at an Australian university. Journal of Teaching in Travel and Tourism, 6(2), 5-22.

Bernard, H. R. (1988). Research Methods in Cultural Anthropology. Newbury Park, California: Sage.

Cantwell, B., Luca, G., \& Lee, J. (2009). Exploring the orientations of international students in Mexico: Differences by region of origin. Higher Education, 573), 335-354.

Crowther, P., Joris, M., Otten, M., Nilsson, B., Teekens, H., \& Wächter, B. (2000). Internationalisation at home A position paper. Amsterdam: European Association for 
International Education.

Dunne, C. (2009). Host students' perspectives of intercultural contact in an Irish university. Journal of Studies in International Education, 13(2), 222-239.

Fanon, F. (2013). 검은 피부 하얀 가면. (이석호 역) 고양: 인간사랑. (원서출판: 1971)

Harrison, N., \& Peacock, N. (2009). Cultural distance, mindfulness and passive xenophobia: Using integrated threat theory to explore home higher education students' perspectives on 'internationalisation at home'. British Educational Research Journal, 36(6), 877-902.

Jon, J.-E., \& Kim, E. Y. (2011). What it takes to internationalize higher education in Korea and Japan: English-mediated courses and international students. In J. D. Palmer, A. C. Roberts, Y. H. Cho \& G. Ching (Eds.), Globalization's influence upon the internationalization of East Asian higher institute. New York: Palgrave Macmillan.

Jon, J.-E. (2012). Power dynamics with international students: From the perspective of domestic students in Korean higher education. Higher Education, 64, 441-454.

Jon, J.-E. (2013). Realizing internationalization at home in Korean higher education: promoting domestic students' interaction with international students and intercultural competence. Journal of Studies in International Education, 174), 455-470.

Ledwith. S., \& Seymour, D. (2001). Home and away: preparing students for multicultural management. The International Journal of Human Resource Management, 12(8), 1292-1312.

Peacock, N., \& Harrison, N. (2009). "It's so much easier to go with what's easy": "Mindfulness" and the discourse between home and international students in the United Kingdom. Journal of Studies in International Education, 13(4), 487-508.

Shin, J. C. (2012). Higher education development in Korea: western university ideas, Confucian tradition, and economic development. Higher Education, 64(1), 59-72.

Spencer-Rodgers, J. (2001) Consensual and individual stereotypic beliefs about international students among American host nationals. International Journal of Intercultural Relations, 25(6), 639-657.

Spencer-Rodgers, J., \& McGovern, T. (2002). Attitudes toward the culturally different: the role of intercultural communication barriers, affective responses, consensual stereotypes, and perceived threat. International Journal of Intercultural Relations, 26 609-631.

Teekens, H. (2007). Internationalisation at home: An introduction. In H. Teekens (Ed.), Internationalisation at home Ideas and ideals (pp. 3-11). Amsterdam: European 
Association for International Education.

The Times Higher Education Ranking (2015).

http://www.timeshighereducation.co.uk/world-university-rankings/2014-15/world-ranking UNITE. (2006). The International Student Experience Report. Bristol: UNITE.

Volet, S. E., \& Ang, G. (1998). Culturally Mixed Groups on International Campuses: an Opportunity for Inter-cultural Learning. Higher Education Research \& Development, 171), 5-23.

Wächter, B. (2003). An introduction: Internationalisation at home in context. Journal of Studies in International Education, 7, 5-11.

Ward, C., Masgoret, A. M., Ho, E., Holmes, P., Cooper, J., Newton, J., \& Crabbe, D. (2005). Interactions with international students: Report prepared for ectucation New Zealand Center for Applied Cross-cultural Research, Victoria University of Wellington.

Wright. S., \& Lander, D. (2003). Collaborative group interactions of students from two ethnic backgrounds. Higher Education Research \& Development, 22(3), 237-251.

* 논문접수 2014년 11월 4일 / 1차 심사 2014년 12월 12일 / 2차 심사 2015년 2월 3일 / 게재승인 2015년 3월 6일

* 임희진: 영국 Nottingham 대학 경영학과를 졸업하고 서울대학교 대학원 교육학과에서 석사학위를 취득하였으며 현재 동대학원 박사과정에 재학 중이다.

*E-mail: liyyhl@snu.ac.kr

* 김제희: 서울대학교 사범대학 교육학과를 졸업하고, 동대학원 교육학과에서 석사과정에 재학 중이다.

*E-mail: jhekim@snu.ac.kr

* 정소현: 부산교육대학교 과학교육과를 졸업하고 현재 서울대학교 교육학과 석사과정에 재학 중이다.

* E-mail: srona21@snu.ac.kr

* 정하영: 이화여자대학교 영어교육과를 졸업하고 현재 서울대학교 교육학과 석사과정에 재학 중이다.

*E-mail: hyc0724@snu.ac.kr

* 김현성: 서울대학교 역사교육과를 졸업하고 서울대학교 교육학과 석사과정을 졸업하였다. 현재 면목중학교에 재직 중이다.

*E-mail: theohyun@hanmail.net 
Abstract

\title{
"Internationalization for whom?"
}

\section{Domestic Students' Perception of Campus Internationalization*}

\author{
Lim, HeeJin** \\ Kim, Jehui \\ Chung, Sohyun \\ Chung, Hayoung \\ Kim, Hyunsung
}

This study explores how Korean students perceive 'campus internationalization'. For analysis, 24 undergraduate and postgraduate students in ' $\mathrm{A}$ ' university have been interviewed. Followings are the results from this study. First, it was found that there was general consensus regarding the necessity of internationalization of Korean higher education among the domestic students. However, students' perceived there are limited benefits they can experience from current internationalization since the purpose of internationalization was resulted from the external pressure (such as performance from global university league table). Second, domestic students had different perception on international students' motivation to choose Korea as their study destination, their attitude and academic ability based on international students' background (nationality, ethnicity etc). Third, domestic students perceived their international peer as 'uncomfortable guest', in a sense where they require constant help and attention from Korean students and the level of such distance was found to be different by students' discipline field and degree program. Fourth, some domestic students had negative perception of international students' relatively easier access on resources (admission, scholarship, placement on dormitory), hence regard them as 'competitors' and source of threat. Based from these results, this study suggested that universities and government must consider domestic students' needs and difficulty thoroughly when putting forward with their internationalization policy.

Key words: Internationalization of higher education, Internationalization at Home, Campus internationalization, domestic student perception

* This work was supported by the Brain Korea 21 Plus Project funded by the National Research Foundation of Korea (No.21B20130011080)

** First author, Ph.D. student, College of Education, Seoul National University 